\title{
渓床堆積物の初期移動——吸い込み・吹き出し速度の粒径別移動限界への影響— Incipient Motion of Debris in Mountain Streams \\ with Particular Reference to Effect of Seepage Flow
}

$\begin{array}{llll}\text { 京都大学工学部 } & \text { 正 } \text { 員 } & \text { 中川 博次 } \\ \text { 金沢大学工学部 } & \text { 正 } \text { 員 } & \text { 辻本 } & \text { 哲郎 } \\ \text { 京都大学工学部 } & \text { 正 員 } \text { ○村上 正吾 }\end{array}$

\section{1. まえがき}

山地河道では崩壊土砂がかなり疎な構造で堆積しでおり（渓床堆積層）, その高い透水性のゆえ, 堆積層 内浸透流も無視し得ない。とくに, 土石流堆積領域では図一 1 のようにその上流域では渓床堆積層内への流 量流入が活発であるし(吸い込み速度の存在), 他方渓床堆積層下流端 部では流量流出が著しい(吹き出し速度の存在)。すなわち、こうした 領域での砂碰の流送に扔いては, これら流出入流速（transpiration velocity）の影響に関心を払わざるを得ない。またこうした渓床堆積物は 一般に粒度分布も広く，これらの流出入流速の影響の度合は必然的に粒 径によって異なるものと考えられる。渓床堆積物の移動限界は土砂流出 予測にとって重要でとくに土石流的集合流動化の限界はこれまでよく議 論されているが, 粒径別に流出入流速の効果をも含めた検討は, 土石流

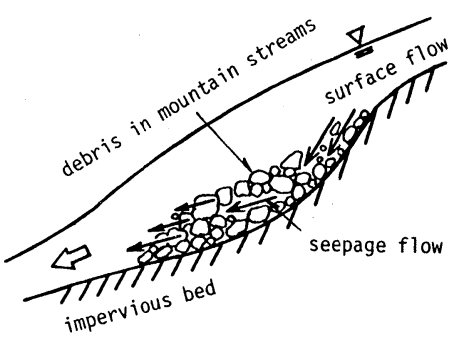

図-1 概念図 の前兆ともなりかねない個々の粒子の運搬, またそれによる粒径別選択流送の継続の結果として生じる渓床 堆積層の粒度構成の変化は, 土石流の初期移動にとって有益な情報を提供するものと思われる。

\section{2. 流出入流速が存在する場での一様砂の初期移動}

流出入流速 $v_{0}$ の初期移動機構に与える影響を検討するために, ここでは浸透流を伴った表面流と，不浸透性河床上の流れが， いずれも同一エネルギー勾配の等流状態であり, 表面流が同一 流量である場合を考える。図一 2 に示すように, 流下方向に $\alpha$ だけ傾いた急勾配透水性河床上での砂れき粒子に作用する力は, 主流による抗力 $D$, 揚力 $L$, 流出入流速による抗力 $D_{s}$, 砂粒の重 量 $W$, 浮力 $B$ 及び摩擦力 $f_{r}$ であり, これらの流下方向合力 $F$ の大 きさを求め, 砂粒の重量 $W$ で無次元化を行うと次の式が得られる。

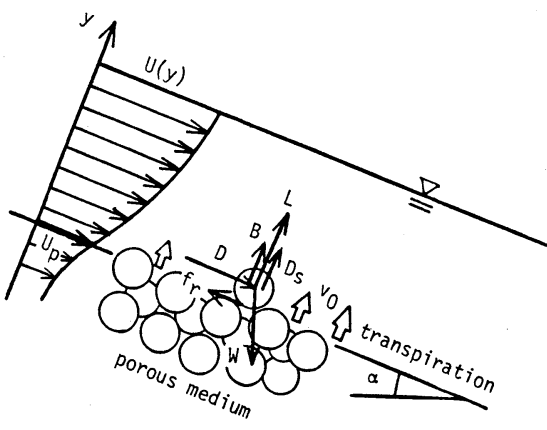

図-2 定義図

$$
F / W=(\dot{D} / W) \cdot\left[1+\left\{k_{L}+\left(D_{s} / D\right)\right\} \mu_{f}\right]-\left[\{\cos \alpha-(B / W)\} \mu_{f}-\sin \alpha\right]
$$

ここに, $\mu_{f}$ : 砂の静止摩擦係数, $k_{L}$ : 揚力と抗力の比である。

$$
\begin{aligned}
& W=\sigma g A_{3} d^{3}, \quad B=\rho g A_{3} d^{3} \\
& D=\varepsilon_{0} C_{D} \frac{1}{2} \rho U_{d}^{2} A_{2} d^{2}, \quad D_{s}=\varepsilon_{0}^{\prime} C_{D}^{\prime} \frac{1}{2} \rho\left|v_{0}\right| v_{0} A_{2} d^{2}
\end{aligned}
$$

とおいて整理すると $\left(\varepsilon_{0}, \varepsilon_{0}^{\prime}\right.$ : 遮蔽係数; $C_{D}, C_{D}^{\prime}$ : 抗力係数; $A_{2}, A_{3}$ : 砂の形状係数; $\sigma$ : 砂の密度;

$\rho:$ 水の密度; $d$ : 砂粒径; $U_{d}$ : 河床砂れきの近傍の局所流速), 次式が得られる。

$$
\begin{aligned}
& F / W=\Xi_{0} \cdot \phi_{0}^{2}\{(\sigma / \rho-1) /(\sigma / \rho)\} \cdot\left\{1+\left(k_{L}+\phi_{1}\right) \mu_{f}\right\}\left(\tau_{*}-\Psi \tau_{*_{c n}}\right) \\
& \Xi_{0} \equiv \varepsilon_{0} \cdot\left(C_{D} A_{2} / 2 A_{3}\right) \cdot\left(U_{d n} / u_{*_{n}}\right)^{2}, \quad \tau_{*} \equiv u_{*}^{2} /\{(\sigma / \rho-1) g d\} \\
& \Psi \equiv\left(1+k_{L} \mu_{f}\right) /\left[\phi_{0}^{2}\left\{1+\left(k_{L}+\phi_{1}\right) \mu_{f}\right\}\right] \\
& \phi_{0} \equiv\left(U_{d}^{+} / U_{d n}^{+}\right) / \sqrt{\Omega}, \quad \phi_{1} \equiv\left(\varepsilon_{0}^{\prime} C_{D}^{\prime} / \varepsilon_{0} C_{D}\right) \cdot\left|v_{0}^{+}\right| v_{0}^{+} / U_{d}^{+2} \\
& \tau_{* c n}=(\sigma / \rho) /\left\{(\sigma / \rho-1) \Xi_{0}\left(1+k_{L} \mu_{f}\right)\right\}\left[\{\cos \alpha-1 /(\sigma / \rho)\} \mu_{f}-\sin \alpha\right]
\end{aligned}
$$


但し, $u_{*}$ : 摩擦速度であり, 下付き添字 $n$ は不浸透性河床での値を示し, 上付き添字十は摩擦速度 $u_{*}$ で無 次元化したことを表しており， $\Omega \equiv\left(u_{*} / u_{* n}\right)^{2}$ である。 $F=0$ はいわゅる移動限界に対応し, これより急勾配 透水性河床上にある砂粒子の無次元限界掃流力 $\tau_{*_{c}}$ は次のように与えられる。

$$
\tau_{* c} \equiv \frac{\sigma / \rho}{\sigma / \rho-1} \cdot \frac{1}{\Xi_{0}} \frac{\{\cos \alpha-1 /(\sigma / \rho)\} \mu_{f}-\sin \alpha}{1+\left(k_{L}+\phi_{1}\right) \mu_{f}} \frac{1}{\phi_{0}^{2}}=\Psi \tau_{* n}
$$

$\Psi$ は, 流出入流速 $v_{0}$ が存在する場合の無次元限界掃流力 $\tau_{*_{c}}$ と無い場合のそれとの比を示しており, $v_{0}$ の効 果を示す指標となる。 ${ }_{* c n}$ を式(8)で与えると, 河床砂れきに作用する流体力の比 $\phi_{0}^{2}$ 及び $v_{0}$ にる流体力の 効果を示す項 $\phi_{1}$ を評価することにより， $\Psi$ は得られる。透水性河床上の流れの流速分布に，河床面上での $\operatorname{slip}$ 速度 $U_{p}$ と流出入流速 $v_{0}$ を境界条件として与えて導びかれた, 次式で表される粗面乱流に対する 2 乗対 数則 ${ }^{1)}$ を適用する。

$$
U^{+} \equiv \frac{U}{u_{*}}=\frac{v_{0}^{+}}{4 \kappa_{0}^{2}}\left(\ln \frac{y}{k_{s}}\right)^{2}+\frac{1}{\kappa_{0}}\left(\frac{v_{0}^{+}}{2} D_{r}+\sqrt{1+v_{0}^{+} U_{p}^{+}}\right) \ln \frac{y}{k_{s}}+\left(\frac{v_{0}^{+}}{4} D_{r}+\sqrt{1+v_{0}^{+} U_{p}^{+}}\right) D_{r}+U_{p}^{+} \quad \cdots(10)
$$

不浸透性河床上の流れの場合は $U_{p}=v_{0}=0$ であり, このとき粗面対数則に一致する。ここで, $\kappa_{0}, D_{r}$ : 普 遍定数; $k_{s}$ : 等価砂粗度である。また, 流水抵抗の比を表す $\Omega$ について, 透水性河床上流れと不浸透性河床 上流れの平均流速公式より得られる次式 ${ }^{1)}$ を用いる。

$$
\sqrt{\frac{2}{f_{n}}}\left[\frac{1}{\Omega}-\sqrt{\Omega+\lambda_{1} \lambda_{2}}-\frac{\lambda_{1}}{2 k_{0}} \ln \Omega\right]=\frac{\lambda_{1}}{4}\left[\frac{2}{f_{n}}+\frac{1}{k_{0}}\left\{(\ln \Omega)^{2}+1\right\}\right]+\frac{\ln \Omega}{k_{0}} \sqrt{\Omega+\lambda_{1} \lambda_{2}}+\lambda_{2} \cdots \text { (11) }
$$

但し， $\lambda_{1} \equiv v_{0}^{+} \cdot \sqrt{\Omega} ; \lambda_{2} \equiv U_{p}^{+} \cdot \sqrt{\Omega} ; f_{n}$ : 不浸透性河床上の流れの抵抗係数で ある。上式による $\Omega$ と $\lambda_{1}$ の関係は $\lambda_{2}$ と $f_{n}$ をパラメータとしており, 図ー 3 に 示される通りである。一方, $\phi_{1}$ 中の抗力係数については, Reynolds 数の全域 にわたって適用できる形式として， $C_{D}, C_{D}^{\prime}$ とに次式で与える。

$$
C_{D}=0.4+24 /\left(U_{d}^{+} \cdot R e_{*}\right) ; C_{D}^{\prime}=0.4+24 /\left(\left|v_{0}^{+}\right| \cdot R e_{*}\right)
$$

ここに, $R e_{*}=u_{*} d / \nu(\nu$ : 水の動粘性係数 $)$ である。主流の抗力を決める局所 代表流速 $U_{d}$ を与える高さを $y=0.7 d$, さらに $k_{s}=d$ とした。とくに境界面 を通過する流出入流速の存在に着目していることより， $U_{p}=0$ とする一方，不 浸透性河床上の流れの抵抗係数 $f_{n}$ をパラメータとして， $\phi_{0}$ 及び $\Psi の v_{0}^{+}$に対す る関係を図ー4(a), (b)に示した。但し, 計算にあたって, $k_{L}=0.85, \mu_{f}=1.0$, $\varepsilon_{0}^{\prime} / \varepsilon_{0}=1, \alpha=0, R e_{*}=80$ とした。図一 3 に示されるよ5に $\lambda_{2}=0$ の場合 でも, transpiration速度と $\Omega$ の関倸（減少関数）は抵抗係数 $f_{n}$ の值に依存する. ので, $\phi_{0} \sqrt{\Omega}$ は $v_{0}$ に対し増加関数であるとはいえ, 吸い込み・吹き出しに対す

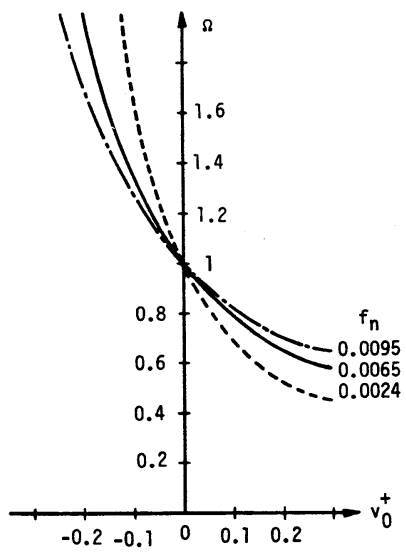
る流出入流速の存在の有無による河床上の 砂れきに作用する局所代表流速の比 $\phi_{0}$ の特 性は, この影響を受け, 河床砂れきの離 脱に対して, 吸い込みが抑制, 吹き出し が促進するとは必ずしも断定できないこ とが示されている。

な㧍，透水性移動床上の流砂モデルを 展開するという点では, 砂粒の pick-up rateを求めることに意味がある。式(1)に おいて $F>0$ のをき, 砂粒子は加速され
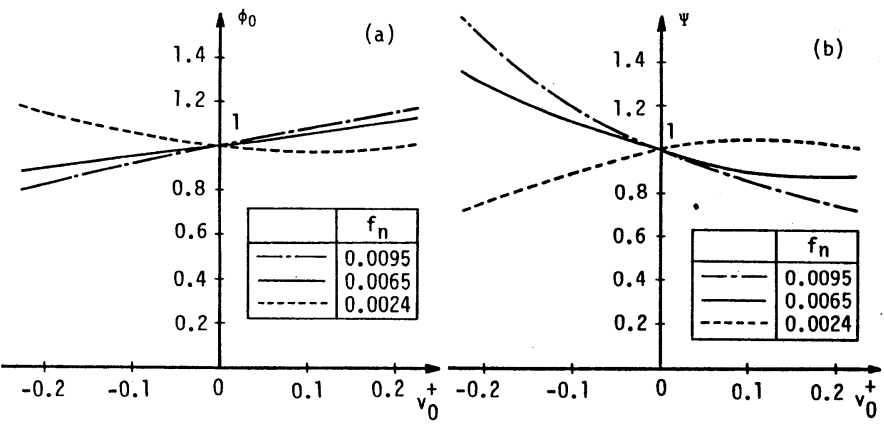

図- $4 \phi_{0}, \Psi$ と $v_{0}^{+}$の関係

て離脱する。このとき, 駆動力 $F$ を受けて離脱する砂粒の運動方程式の解に, 流体力の変動の効果をとり入 れて, pick-up rateの推定式として次式が得られる。 


$$
p_{s *}=\left(F_{0} / \Psi\right) \cdot\left\{1-\left(k_{2} \Psi_{* c n} / \tau_{*}\right)\right\}^{n}
$$

中川 $5^{2)}$ の不浸透性平坦河床での理論及び実験結果を援用 すると $F_{0}=0.03, k_{2}=0.7, n=3$ である。上式によって 計算された $p_{s *} \sim \tau$ 関係を図一 5 に示した。計算において は, 前述した数值を用い, また路床勾配については， $\alpha$ $=0$ 及び $\alpha=10$ (度)とした。

ところで, 上述のように同一のエネルギー勾配・単位 幅流量の等流状態での透水性及び不浸透性河床での限界 掃流力の比を求めるためには, $\Omega$ の值の評価が重要で, これは不浸透層上流れの抵抗係数 $f_{n}$ によって変化する。 そのため, 均一砂の場合には, それが比較的簡単に評価 されるものの, 混合砂を対象とすると混合砂れき床全体
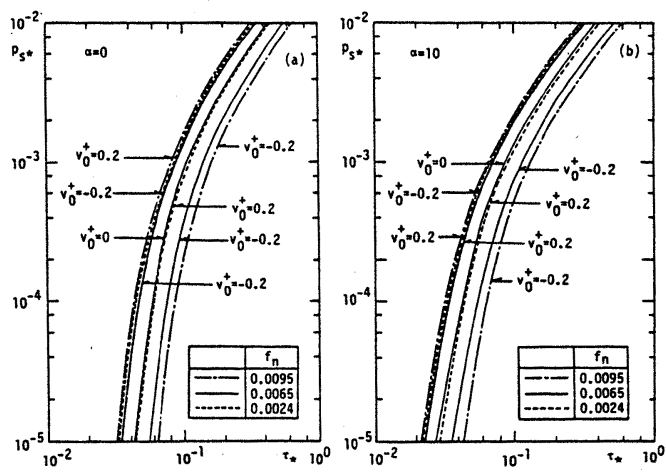

図一 $5 \quad v_{0}^{+}, f_{n}$ による pick-up rateの変化

としての流れの抵抗係数の評価も行わねばならず, 今回対象とする流出入流速の影響が混合砂の粒径別の挙 動にどのように異質に効くかの検討にとっては非常に厄介となり，目的とする効果を明確に表示し得ない。 そこで次のように流出入流速の無いときの掃流力に換算した限界掃流力 $\tau_{c}^{T}$ を対象とする。すなわち, 流出入 流速が存在する場合の限界掃流力 $\tau_{c}$ に対して， $v_{0}$ による付加的な掃流力を除いた仮想的な限界掃流力 $\tau_{c}^{T}$ を考えると, $\tau_{c}$ と $\tau_{c}^{T}$ の間には次式で与えられる関係が成立する。

$$
\tau_{c}^{T} \equiv(1 / \sqrt{\Omega}) \cdot \tau_{c}
$$

この仮想的な $\tau_{c}^{T}$ と流出入流速の無い状況での限界掃流力 $\tau_{c n}$ との比 $\widetilde{\Psi}$ は, 次のように $\Omega \sim v_{0}^{+}$の関係を含まないで評 価される。

$$
\begin{aligned}
& \widetilde{\Psi} \equiv \tau_{c}^{T} / \tau_{c n}=\left(1+k_{L} \mu_{f}\right) /\left[\widetilde{\phi}_{0}^{2}\left\{1+\left(k_{L}+\phi_{1}\right) \mu_{f}\right\}\right] \\
& \widetilde{\phi}_{0} \equiv U_{d}^{+} / U_{d n}^{+}
\end{aligned}
$$

$\Psi$ と $\widetilde{\Psi}$ と関係は, 式(6)と(15)を比較することより次のように与えられる。

$$
\widetilde{\Psi}=(1 / \Omega) \cdot \Psi
$$

したがって, $\widetilde{\Psi}$ え求めておけば上式にもとつき容易に $\Psi$ に変換ができる。

\section{3. 流出入流速が存在する場での混合砂の初期移動}

混合砂れき床よりの砂粒の離脱に関しては, 従来より粒径別の移動限界掃流力として研究が進められており, 河床上の各粒径に作用する局所代表流速の.河床面よりの高さの差に起因するとした Egiazaroff ${ }^{3)}$ の取り扱いが比 較的合理的な方法と考えられている。しかしながら, Egiazaroff ${ }^{3)}$ のモデリングは単に対数則の基準面からの 流速の作用位置のみに注目しており，混合砂れき床特有の砂粒の配列状態には言及しておらず，また等価砂 粗度 $k_{s}$ の評価もあいまいのままである。本研究では, 流出入流速の無い条件でこうした点をも考慮した中川 $ら^{4)}$ の解析に基本的に従って検討を進める。

一様砂の場合には, 同一エネルギー勾配の等流状態で, 表面流流量が同一である場合を対象にしたが, 流 れの抵抗係数 $f_{n}$ の決定が難しいことから, 前節で定義した仮想の限界掃流力 $\tau_{c}^{T}$ を用い, 流出入流速の混合 砂の流径別移動限界に与える影響の検討を行う。一様砂の場合と同様, 透水性河床上の砂粒径 $d_{i}$ の砂れきに 作用する力は, 主流による抗力 $D_{0 i}$, 揚力 $L_{i}$, 流出入流速による抗力 $D_{s i}$, 砂粒の重量 $W_{i}$, 浮力 $B_{i}$ 及び摩擦 力 $f_{r i}$ である。移動限界掃流力付近での砂れきの離脱形式を滑動とみなし, 流下方向の合力 $F_{i}$ を砂の重量 $W_{i}$ で無次元化すると次式が得られる。

$$
F_{i} / W_{i}=\left(D_{i} / W_{i}\right) \cdot\left[1+\left\{k_{L}+\left(D_{s i} / D_{i}\right)\right\} \mu_{f}\right]-\left[\{\cos \alpha-(B / W)\} \mu_{f}-\sin \alpha\right]
$$

一様砂の場合と同様に無次元化を行い整理すると次のようになる。

$$
F_{i} / W_{i}=\{(\sigma / o-1) /(\sigma / \rho)\} \cdot\left\{\left(1+k_{L} \mu_{f}\right) \Xi_{o i} / \Psi_{i}\right\} \cdot\left(\tau_{* i}-\Psi_{i} \tau_{* o n i}\right)
$$




$$
\begin{aligned}
& \Xi_{0 i}=\varepsilon_{0 i}\left(C_{D} A_{2} / 2 A_{3}\right) \cdot U_{d n i}^{+2}=\Xi_{0} \cdot\left(U_{d n i}^{+} / U_{d n m}^{+}\right)^{2} \quad \ldots \ldots \ldots \ldots \ldots(20) \\
& \Psi_{i}=\widetilde{\Psi}_{i} \cdot \Omega \\
& \widetilde{\Psi}_{i}=\left(1+k_{L} \mu_{f}\right) /\left[\widetilde{\phi}_{0 i}^{2}\left\{1+\left(k_{L}+\phi_{1 i}\right) \mu_{f}\right\}\right] \quad \quad \ldots \ldots \ldots \ldots \ldots \text { (22) } \\
& \widetilde{\phi}_{0 i}=U_{d i}^{+} / U_{d n i}^{+} ; \quad \tau_{* i}=u_{*}^{2} /\left\{(\sigma / \rho-1) g d_{i}\right\} \quad \ldots \ldots \cdots \cdots \cdots(23)
\end{aligned}
$$

ここで, 添字 $i$ は各粒径の砂についての諸量を, 添字 $m$ は平均粒径の砂についての諸量を示す。各粒径ごと の無次元限界掃流力 $\tau_{* c i}$ は $F_{i}=0$ とおくことにより， $\tau_{* c i}=\Psi_{i} \cdot \tau_{* c n i}$ で与えられる。ところで, 流出入流速が 存在する場合, 一様砂の限界掃流力 $\tau_{* c o}$ に対する粒径別限界掃流力 $\tau_{* c i}$ の比は次式で与えられる。

$$
\tau_{* c i} / \tau_{* c o}=\left(\Psi_{i} / \Psi\right) \cdot\left(\tau_{* c n o} / \tau_{* c n i}\right)
$$

$\left(\tau_{* c n i} / \tau_{* c n o}\right)$ は粗面対数則を適用して次式で与えられる。

$$
\frac{\tau_{* c n i}}{\tau_{* c n o}}=\left(\frac{U_{d n i}^{+}}{U_{d n o}^{+}}\right)^{2}=\left[\frac{\ln \left\{30.1\left(y_{0} / k_{s o}\right)\right\}}{\ln \left\{30.1\left(y_{i} / k_{s}\right)\right\}}\right]^{2}
$$

但し， $y_{i}$ は粒径 $d_{i}$ の砂れきの中心の基準面からの高さであり，下付添字 0 は均一砂に対する值を示す。この 式は, 混合砂れき床の粒径別無次元移動限界掃流力は粒子の存在する高さ $y_{i}$ と混合砂れき床としての等価砂 粗度 $k_{s}$ に支配されていることを示しており，中川ら ${ }^{4)}$ はさらに粒径別の抜け出し角の相違も影響することを明

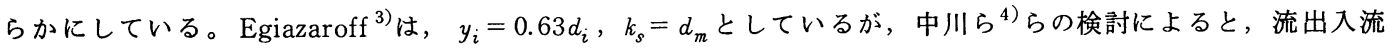
速が無い場合の各粒径の対数則の基準面よりの局所流速の作用位置としては, 混合砂の粒度分布にほとんど 無関係に， $y_{i}=0.5 d_{i}$ とすればよいことを明らかにしており，ここでも，流出入流速の存在の有無にかかわら ず, 局所流速の作用位置として $y_{i}=0.5 d_{i}$ を採用することとする。一方, 等価砂粗度 $k_{s}$ にいては, その合 理的な評価のため「相当径」( equivalent size) の概念を導入している。すなわち, 各砂れきに働く抗力の単 位面積当りの総和が，対象とする混合砂れき床と等しくなるような均一粒径砂れきより成る河床を求め, 粗度 特性が一致すると見なし，この相当径 $d_{e}$ を $k_{s}$ としている。流出入流速が存在する場合においても, 同様の手 法で粗度特性が同一視できる相当径 $d_{e}$ を求め, $k_{s}$ とするのが望ましいと考えられるが， 2 乗対数則の式形が 複雑であること，しかしながら，混合砂の粒度分布の特性を少しでも反映させることを勘案して，ここでは，

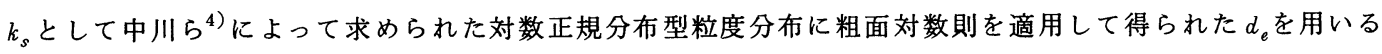
こととする。

均一砂の場合と同様の定数を用い, $U_{p}=0$ とした場合の, 各砂粒 径 $d_{i}$ の平均粒径 $d_{m}$ に対する比 $\zeta_{i} \equiv\left(d_{i} / d_{m}\right)$ をパラメータとして, $\phi_{0 i}$ 及び $\widetilde{\Psi}_{i}$ の $v_{0}^{+} に$ 対する変化を示したものが図一 6 である。この図によ ると, 流出入流速の存在の $\widetilde{\phi}_{0 i}, \Psi_{i}$ に与える影響は $\zeta_{i}>1$ (粗粒分) に対しては均一砂の場合に比べ著しいのに対し， $\boldsymbol{\zeta}_{i}<1$ (細粒分) に対しては緩慢であることがわかる。なお， $\widetilde{\phi}_{0 i}, \Psi_{i}$ と斿関係に及 ぼす粒度分布の広がり（例えば幾何標準偏差 $\sigma_{g}$ ) の効果はそれほど 有意なものではない。一方, 図一 7 は, 流出入流速がある場合の混 合砂の平均粒径に等しい均一砂に対する無次元限界掃流力と粒径別 無次元限界掃流力の比 $\left(\tau_{* c i} / \tau_{* c o}\right)$ を示したものである。この図に よると, 吹き出しに対しては細粒分の運動が抑制され, 粗粒分の運 動は促進される。一方吸い出しに対しては逆の様相である。図にお いて $\zeta_{i}=1$ のところで $\left(\tau_{* c i} / \tau_{* c o}\right)<1$ となっているのは, 半均粒 径の砂が均一砂の状態にあるよりも混合砂の状態にある方が動き易 いことを示しており，これは，混合砂れき床の等価砂粗度の評価に 起因するものである。なお，これに伴って，( $\left(\tau_{* c i} / \tau_{* c o}\right) \sim \zeta_{i}$ 関倸は 粒度分布の広がり（ $\sigma_{g}$ を指標としている）による流出入流速の影響

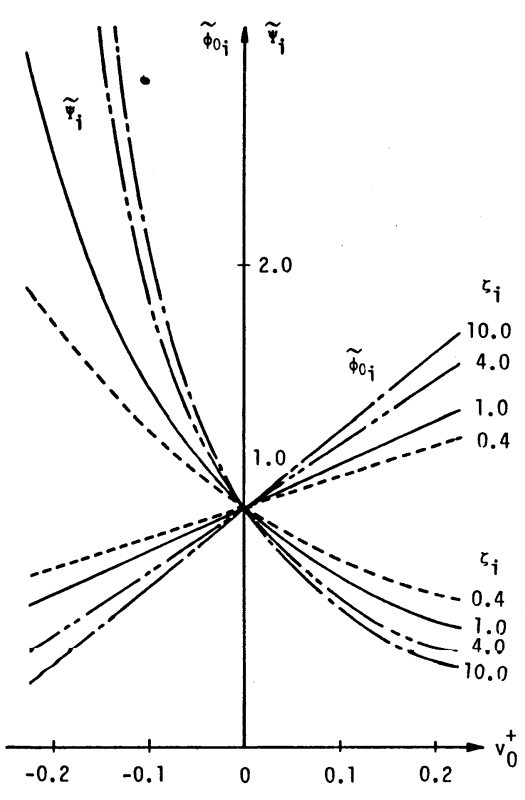

図-6 $\widetilde{\phi}_{o i}, \widetilde{\Psi}_{i}$ と $v_{0}^{+}$の関係 


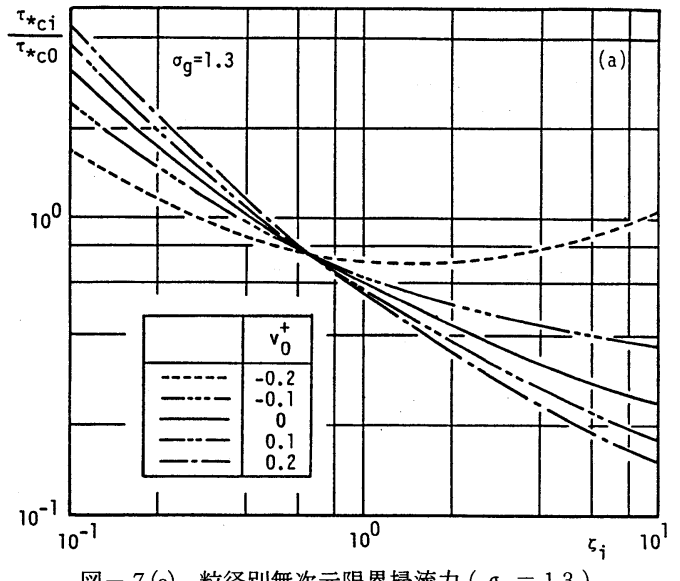

図-7 (a) 粒径別無次元限界掃流力 $\left(\sigma_{g}=1.3\right)$

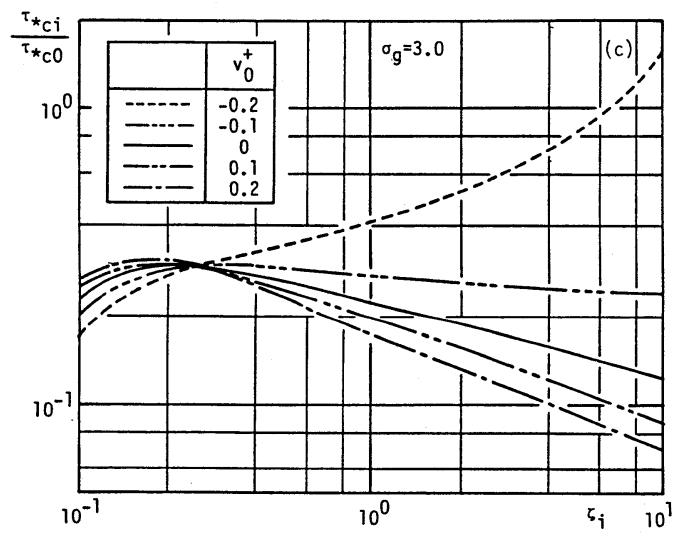

図-7(c) 粒径別無次元限界掃流力 $\left(\sigma_{g}=3.0\right)$

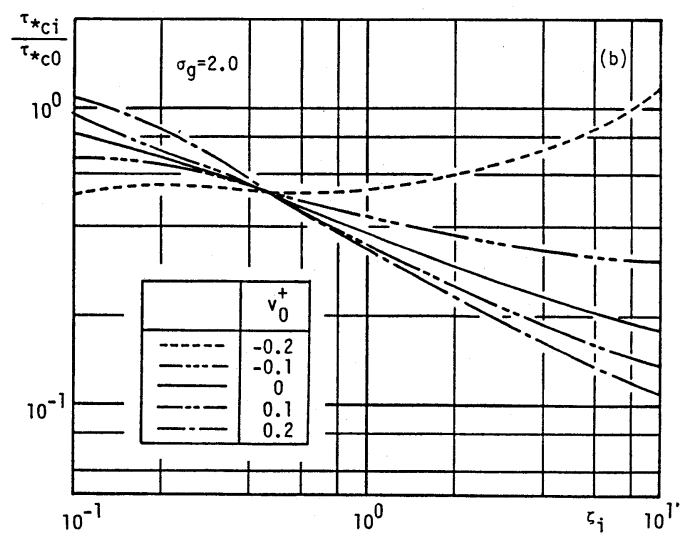

図 -7 (b) 粒径別無次元限界掃流力 $\left(\sigma_{g}=2.0\right)$

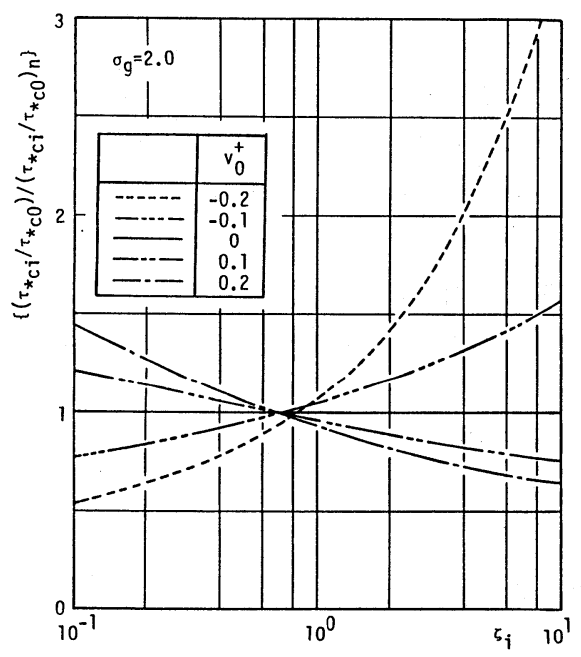

図-8 $\left\{\left(\tau_{*_{c i}} / \tau_{* c o}\right) /\left(\tau_{* c i} / \tau_{* c n}\right)_{n}\right\}$ と $\zeta_{i}$ の関倸

の相違が著しいことも示されている。一方, 図一 8 は粒径別無次元移動限界掃流力と均一砂のそれとの比が, 流出入流速の存在によってどのように変化するかを示したもので, 横軸に $\zeta_{i}$, 縦軸に $\left\{\left(\tau_{* c i} / \tau_{* c o}\right) /\left(\tau_{* c i} / \tau_{* c o}\right)_{n}\right\}$ がとられている。こうした比をとれば，粒度分布の広がりによる差はほとんどなく，小粒径のものは，吸い 込みによって粒径別無次元限界掃流力 $\left(\tau_{* c i} / \tau_{* c o}\right)$ が小さくなり，逆に吹き出しによって $\left(\tau_{* c i} / \tau_{* c o}\right)$ が大き くなることがわかる。

粒径別の pick-up rate については, 均一砂と同様の手法により, 滑動離脱の運動方程式にもとついて求め ると次のようになる。

$$
p_{s * i} \equiv p_{s i} \sqrt{\frac{d_{i}}{(\sigma / \rho-1) g}}=F_{0} \frac{\tau_{* c n o}}{\tau_{* c n i}} \frac{1}{\Psi_{i}} \tau_{* i}\left(1-\frac{k_{2} \Psi_{i} \tau_{* c n i}}{\tau_{* i}}\right)^{n}
$$

$F_{0}, k_{2}, n$ の定数については, 均一砂の場合と同様とする。上式にもとゔいて, 河床勾配 $\alpha=0$ として, 無 次元化された流出入流速 $v_{0}^{+}$を゚ラメータにし, 粒度分布が対数正規分布に従う場合の粒径別無次元底面せん 断応力 $\tau_{* i}\left(\equiv u_{*}^{2} /\left\{(\sigma / \rho-1) g d_{i}\right\}\right)$ と無次元粒径別 pick-up rate $p_{s * i}$ との関係を示したものが図一 9 である。 流出入流速の存在が粒径別 pick-up rateに及ぼす影響は，ら みは粒径別限界掃流力に与える影響が大きいため， pick-up rate の值自体に与える影響も大きくなっている。 


\section{4. あとがき}

本研究では渓床堆積物の広い粓度分布と, 渓床堆積層の 高い透水性にもとうく流出入流速の出現の効果に着目し， 各個運搬, 粒径別選択輸送の土石流化に果たす役割に鑑み, その移動限界を理論的に検討したものである。流出入流速 の存在による表面流乱流構造の変化は，2 乗対数則を用いて 表現し，また粒径別移動限界については本質的に Egiazaroff の考え方を適用した。但し，等価砂粗度の評価に粒度分布 の広がりの効果をも表現し得る中川らによって提案された 「相当径」の概念を適用した。

まず，均一砂に対する検討が進められ，吹き出し，吸い 込みが必ずしも初期移動の促進，抑制に作用するわけでな いことが明らかにされた。このように評価された流出入流 速の存在する場での均一砂の限界掃流力に対し，そこでの混 合砂の場合の粒径別限界掃流力の比が理論的に誘導された。 この結果，細粒分に対しては吹き出しが抑制，吸い込みが 促進と作用するのに対し，粗粒分に対しては逆に作用する ことなど興味深い事項が検討された。現在, こうした事項 の実験的検討を進めており，理論の検証を行うとともに， 山地河道の土砂流出の見積り精度の向上を図りたいと考え ている。

なお, 本研究の一部は昭和 60 年度文部省科学研究費一般研究 (B)「水流と流砂の相互作用に関する研究」 ( 代表・中川博次) の補助を受けて行われたものである。

参 考 文 献

1）辻本哲郎・中川博次：移動床流れにおける浸透流の存在の意義，第 29 回水理講演会論文集，pp. $525 \sim$ 530,1985

2）中川博次・辻本哲郎：水流による砂れきの移動機構に関する基礎的研究，土木学会論文報告集，第 244 号, pp. $71 \sim 80,1975$

3) Egiazaroff, I. V. : Calculation of nonuniform sediment concentration. Proc. ASCE, Vol.91, HY4, pp. $73 \sim 80,1965$

4）中川博次・辻本哲郎・中野晋 : 混合砂れき床の粗度と粒径別移動限界, 第 25 回水理講演会論文集, pp. $67 \sim 72, \quad 1982$

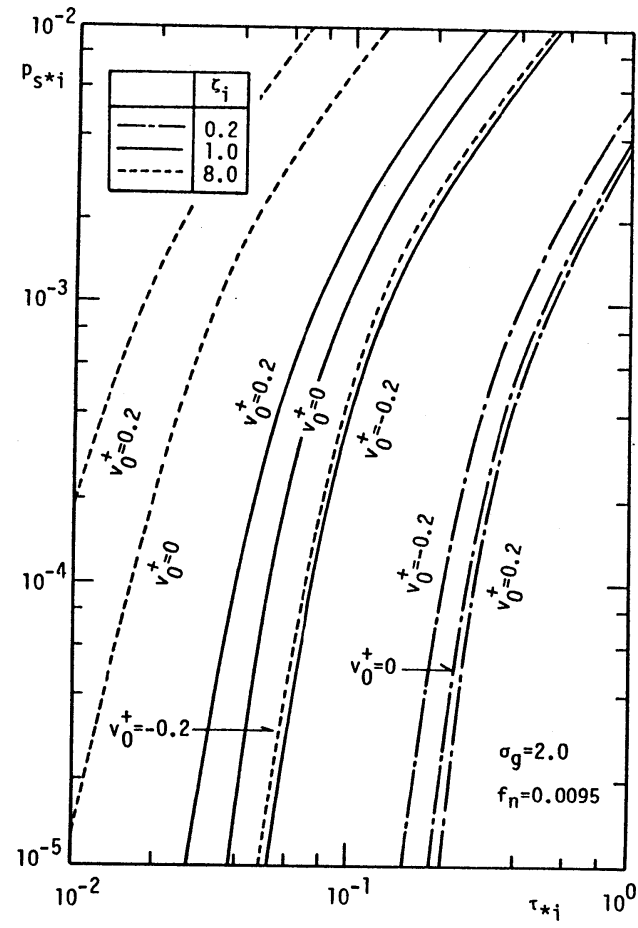

図-9 粒径別無次元 pick-up rate 